\title{
ПСИХОЛОГІЧНІ АСПЕКТИ ВІКОВИХ КРИЗ ОСОБИСТОСТІ ВІД НАРОДЖЕННЯ ДО ЮНАЦТВА
}

Стаття присвячена динаміці змін вікових етапів розвитку, початком $і$ завершенням кожного з яких $\epsilon$ переживання криз, які виводять до нових якісних змін психологічного та сочіального контексту особистості. У статті здійснено теоретичний аналіз вікових криз від народження до юнацького періоду як закономірних етапів психічного розвитку особистості дитини. Визначено хронологічні межі вікових криз. Здійснено класифікацію ознак, симптомів та типологію вікових криз. Зазначено, щзо вікові кризи вносять конструктивні новоутворення в структуру особистості, завдяки яким вона отримує новий досвід, який поділяється на внутрішній, або суб'єктивний, і соціальний (зовнішній), або об'єктивний.

Ключові слова: критичні періоди, стабільні періоди, вікова криза, криза новонародженості, комплекс пожвавлення, криза 3-х років, криза 6-7 років, підліткова криза, юнацька криза.

Статья посвящена динамике изменений возрастных этапов развития, началом и завершением каждого из которых есть переживание кризисов, выводят к новым качественным изменениям психологического и социильного контекста личности. В статье осуществлен теоретический анализ возрастных кризисов от рождения до юношеского периода как закономерных этапов психического развития личности ребенка. Определены хронологические границы возрастных кризисов. Осуществлена классификаџия признаков, симптомов и типология возрастных кризисов. Отмечено, что возрастные кризисы вносят конструктивные новообразования в структуру личности, благодаря которым она получает новый опыт, который делится на внутренний или субъективныци, и социильный (внешний), или объективный.

Ключевые слова: критические периоды, стабильные периоды, возрастной кризис, кризис новорожденности, колплекс оживления, кризис 3-х лет, кризис 6-7 лет, подростковый кризис, юношеский кризис.

Постановка проблеми. Питання теоретичного аналізу вікових криз від народження до юнацького періоду є надзвичайно актуальним, так як стрімкі зміни в суспільстві стимулюють дитину до безперервного розвитку, а лабільність соціальних норм розмиває орієнтири розвитку особистісної ідентичності. Серед різних форм ідентичностей найбільш загальними і розділеними є вікові орієнтири як основа самоідентифікації особистості дитини. Вивчення психологічних закономірностей вікових криз особистості (симптомів, особливостей протікання, головних новоутворень) дозволить виробити загальні принципи i розробити індивідуальні стратегії психологічного супроводу особистості дитини в періоди криз. Це одна з істотних причин, яка викликає необхідність розробки загально психологічної концепції вікових криз розвитку особистості.

Аналіз останніх досліджень і публікацій. У різні періоди життя людини відбуваються зміни в іiі психіці. Вони можуть розгортатися повільно і поступово (еволюційні зміни). У кризові періоди розвитку і становлення індивіда ці зміни раптово вибухають, розвиваються бурхливо і швидко, призводячи до глибоких наслідків. Цей психологічний феномен позначений поняттям «вікові кризи». Вікові кризи - особливі, перехідні періоди розвитку людини, які характеризуються психологічними змінами і нею переживаються.

Феномен вікових криз як психологічного явища в контексті теорій періодизації розвитку людини досліджували такі вітчизняні та зарубіжні науковці: Л. Виготський, Д. Ельконін, О. Запорожець, Л. Божович, Я. Неверович, В. Давидов, Л. Обухова, І. Славіна, І. Кон, О. Донченко, Т. Титаренко, С. Холл, 3. Фрейд, Е. Еріксон та ін. [3; 5; 6; 7]. Дослідники встановлюють індивідуальні характеристики переживання вікових криз розвитку та зараховують їх до природних процесів формування особистості. На думку Л.С. Виготського, криза, чи критичний період, - час якісних позитивних змін, результатом яких є перехід особистості на більш високий щабель розвитку. Зміст кризи - це руйнування соціальної ситуації розвитку, що склалась та виникнення нової [5]. У сучасній психології ще не вироблено єдиного погляду на вікові кризи. Одні дослідники вважають їх ненормальним, болісним явищем, результатом неправильного виховання, інші - вбачають у кризах конструктивну функцію, вважаючи їх закономірним, неминучим явищем. Очевидно, більшу рацію мають ті, хто називає вікову кризу природним явищем, оскільки протягом життя її переживають усі люди. За своєю суттю вона є внутрішнім конфліктом 3 приводу життя, його сенсу, головних цілей i шляхів їх досягнення. Переживання людиною кризи тісно пов'язане 3 глибиною і гостротою 
усвідомлення кризового стану, з рівнем особистісної зрілості, із здатністю ії до рефлексії. Вікова криза визріває всередині особистості, настання їі спричинюється тим, наскільки людина засвоїла все, що необхідно було опанувати на певному віковому етапі. Т. Титаренко визначає кризу як конфлікт між актуальним, сьогоднішнім напрямком життєвого шляху та майбутньою магістральною лінією, головною життєвою траєкторією. [5]

Формулювання цілей статті. Метою нашої роботи $є$ виконання теоретичного аналізу наукових підходів до проблеми вікових криз як природних закономірностей психічного розвитку особистості від народження до юнацтва; сформулювати власну точку зору 3 порушеної проблематики; визначити загальну психологічну характеристику симптомів та ознак вікових криз; окреслити головні новоутворення як детермінанти рушійного розвитку після вікових криз.

Виклад основного матеріалу дослідження. Розвиток дитини є нерівномірним. На одних етапах зміни у дитячій психіці відбуваються повільно та поступово (стабільні періоди), на інших бурхливо й швидко (критичні періоди). Послідовність розвитку визначається чергуванням стабільних і критичних періодів. Незначні та малопомітні для оточення зміни під час довгих стабільних періодів зумовлюють появу вікових новоутворень внаслідок якісних стрибків у розвитку під час криз. Критичні періоди розвитку були відкриті емпіричним шляхом, причому непослідовно (криза семи, трьох, тринадцяти, першого року i, нарешті, криза новонародженості). За влучним висловом Л.Виготського, якби кризи не відкрили емпірично, їх необхідно було б сформулювати теоретично [7]. Під час кризи дитина за дуже короткий термін змінюється у своїх основних рисах. Це революційний, бурхливий, стрімкий перебіг подій як за темпами, так і за змістом змін, що відбуваються.

Для критичних періодів характерні певні особливості:

1. Їх межі вкрай невиразні, розмиті. Криза настає непомітно, дуже важко визначити момент iї початку й завершення. Різке загострення (кульмінація) спостерігається лише всередині цього етапу.

2. Апогей кризи для оточення виявляється у зміні поведінки дитини, іiі «важковиховуваності». Дитина ніби виходить 3-під контролю дорослих, стає вередливою, стрімко знижується успішність у школі та працездатність, зростає кількість конфліктів з оточенням. Внутрішнє життя пов'язане з болісними переживаннями.

3. Розвиток під час кризи має переважно негативний характер. На відміну відстабільних періодів, тут відбувається швидше руйнівна, ніж творча робота. Дитина не стільки здобуває, скільки щось втрачає з надбаного раніше. Водночас у критичні періоди спостерігаються й конструктивні процеси розвитку, поява новоутворень, що мають перехідний характер і не зберігаються надалі у тому самому вигляді (наприклад, автономна мова однорічних дітей).

Період розвитку дитини від народження до одного року називають стадією немовляти. У ній визначають важливу фазу новонародженості (від моменту народження до одного-двох місяців). Фізично відокремившись від матері, дитина має адаптуватися до інших умов життя. Криза новонародженості - проміжний період між внутрішньоутробним і позаутробним способом життя: народжуючись, дитина потрапляє в зовсім нові умови - холод, яскраве світло, повітряне середовище, яке вимагає іншого типу дихання і т.д. Пристосовуватися до нових умов життя дитині допомагають спадково закріплені механізми - безумовні рефлекси (харчові, захисні та орієнтовні). Ознакою кризи є втрата дитиною ваги у перші дні після народження. За умови вдоволення органічних потреб та дотримання правильного режиму і виховання у дитини формуються нові, власне людські потреби (в отриманні вражень, у спілкуванні з дорослими тощо), на їх основі здійснюється психічний розвиток. Поступово на появу дорослого в дитини виробляється специфічна емоційно-рухова реакція («комплекс пожвавлення» за Н.Фігуріним, М.Денисовою), яку вважають початком другої фази розвитку немовляти.

Комплекс пожвавлення - специфічне психічне новоутворення, що слугує межею критичного періоду новонародженості, а час його появи є основним критерієм нормальності психічного розвитку дитини. Соціальна ситуація життя немовляти з матір'ю спричиняе появу нового типу діяльності безпосереднього емоційного спілкування дитини і матері. Згідно з дослідженнями Д. Ельконіна й М. Лісіної, специфічна особливість цієї діяльності полягає в тому, що ії̈ предметом є інша людина.

Протягом першого року в житті дитини відбувається різка зміна ситуації, яка виявляється в переході від біологічного типу розвитку (несформованості поведінки, безпорадності, потреб у їжі й теплі) до соціального (активності, потреб у взаємодії з іншою людиною, пізнанні навколишнього світу), що, як правило, дається їй дуже непросто, породжує кризові переживання. Криза першого року життя - криза, яка обумовлена руйнуванням необхідності емоційної взаємодії дитини з дорослим i проявляється в плаксивості, похмурості, інколи в порушенні сну, втраті апетиту тощо. Головною ознакою кризи першого року є різке зростання незалежності дитини від дорослих: вона опановує ходьбу і предметні дії, стає активнішою, $з$ нею не можна не рахуватися. За такої ситуації 
загострюються переживання, чутливість до різноманітних впливів. Протягом цього періоду розвитку важливим $є$ встановлення соціальних зв'язків дитини з усіма членами сім'ї (дорослими та іншими дітьми). Усе це зумовлює появу в результаті кризових переживань почуття довіри немовляти до об'єктів навколишнього світу. Усвідомлюючи значущість кризового періоду в житті дитини, дорослі повинні вчасно перебудувати стосунки з нею, надати їй більше свободи і самостійності. У річному віці соціальна ситуація розвитку різко змінюється. Ще недавно безпорадна дитина, будь-яка потреба якої опредмечувалася дорослим, тепер уже багато чого навчилася. Здатність самостійно пересуватись відкрила для неї загадковий світ предметів. Якщо раніше дорослий був центром її світу, то тепер вона мовби заворожена предметами. З'являються перші афективні реакції - сильні короткочасні нервовопсихічні збудження, пов'язані переважно з невдачами, які виникають у процесі засвоєння предметних дій. Зв'язок між дитиною і дорослим опосередковується предметом.

Нормальне подолання кризи першого року життя спричинює розпад «Ми» (дитина і мама єдине ціле), становлення першої форми «Я» особистості дитини. Кризу першого року життя не вважають гострою. Встановлення нових стосунків з дитиною, надання ій певної самостійності у дозволених межах, терпіння й витримка дорослих пом'якшують характер кризи. Основними новоутвореннями цього періоду розвитку є формування структури мовної та предметної дії. Поява та зникнення автономної мови знаменує початок і кінець кризи першого року.

Межа між раннім і дошкільним віком - один із найважчих моментів у житті дитини. Одним 3 наслідків інтенсивного розвитку спільної діяльності дитини і дорослого у ранньому віці $\epsilon$ формування в дитини системи власного «Я»- центрального новоутворення, що виникає наприкінці цього етапу (Л. Божович). Малюк вчиться відокремлювати себе від дорослого, починає ставитися до себе як до самостійногоЯ», тобто в нього з'являються початкові форми самосвідомості. Усе це сприяє розвитку прагнення дитини хоча б у вузьких межах своїх можливостей діяти самостійно, без допомоги дорослих («Я сам»). Цей період вважають критичним («криза трьох років»), оскільки дорослі мають труднощі у взаєминах з дитиною.

Поширена криза трьох років уперше була описана Ельзою Келер у праці «Про особистість трирічної дитини» [4]. Вона визначає низку важливих симптомів цієї кризи:

1. Негативізм - негативна реакція не на саму дію, яку дитина відмовляється виконувати, а на вимогу або прохання дорослого.

2. Уnертість - це реакція дитини, котра наполягає на чомусь не тому, що їй цього дуже хочеться, а тому, що сама про це сказала дорослому і вимагає, щоб на ii думку звернули увагу. Малюк починає усвідомлювати себе як особистість і хоче, щоб на цю особистість зважали.

3. Примхливість близька до негативізму і упертості, але має більш генералізований i безособистісний характер. Це протест домашнього устрою, що спрямований не проти конкретного дорослого, а проти всієї системи взаємин, що склалися в ранньому дитинстві, проти прийнятих у сім'ї норм виховання. Дитина хоче все робити і вирішувати сама. Під час криз гіпертрофована тенденція до самостійності призводить до свавілля - прагнення емансипації від дорослого. Дитина хоче бути самостійною. Це дещо нагадує кризу першого року, але тоді було прагнення фізичної самостійності, а тепер ідеться про глибший рівень - самостійність наміру, задуму.

4. Прагнення до самостійності часто неадекватне можливостям дитини і викликає додаткові конфлікти $з$ дорослими. У деяких дітей конфлікти з батьками стають регулярними, вони постійно перебувають у стані війни з дорослими. Тоді говорять про протест-бунт. У сім'ї з єдиною дитиною може з'явитися деспотизм. Якщо в сім'ї. декілька дітей — можуть виникнути ревнощі.

5. Знецінення проявляється в тому, що дитина може почати сваритися (знецінюються старі правила поведінки), відкидати і навіть ламати улюблені іграшки, запропоновані невчасно. У дитини змінюється ставлення до інших людей і до самої себе. Психологічно вона відділяється від близьких дорослих.

Криза трьох років пов'язана з усвідомленням себе як активного суб'єкта у світі предметів, дитина вперше може чинити всупереч своїм бажанням. Із кризи трьох років дитина виходить із бажанням діяти автономно і 3 системою самооцінки. Головне джерело діяльності дитини дорослий. Схвалення і похвала дорослого породжують відчуття гордості і власної гідності. Становлення такої системи «Я», де точкою відліку є досягнення, оцінені іншими, означає перехід до дошкільного дитинства. Описана криза $\epsilon$ тимчасовою, але пов'язані 3 нею новоутворення (відокремлення від оточення, порівняння з іншими тощо) - важливий етап у психічному розвитку дитини. Прагнення самостійності в дитини цього віку виявляється у формі гри, тому криза трьох років і розв'язується шляхом переходу дитини до ігрової діяльності.

Вік 5 - 7 років - це час підготовки до школи, виховання самостійності, незалежності від дорослого, зміна самосвідомості, коли дитина вчиться брати на себе відповідальність за різні сфери 
свого життя. Зміна самосвідомості спричиняє переоцінку цінностей. Переживання узагальнюються. Це період народження соціального «Я» дитини, коли втрачається дитяча безпосередність і виникає нове внутрішнє життя, осмислене орієнтування у власних переживаннях. Завдяки цьому в дитини 3'являються деякі особливості, що характеризують кризу семи років: дитина починає вередувати; вона стає непосидючою; в іiі поведінці з'являються суперечливість, клоунада (вдає із себе блазня), тобто поведінка стає немотивованою (химерною, штучною, манерною, натягнутою). При цьому в дитини виникає нове ставлення до себе, логіка відчуттів, осмислене орієнтування у власних переживаннях. Батьки перестають бути єдиним безумовним авторитетом дитини, з'являється вчитель - «чужий дорослий», також наділений незаперечною владою. Дитина вперше зустрічається із системою жорстких культурних вимог, що пред’являються вчителем, стає об єктом оцінки. Провідна діяльність дитини в цей період - навчання. У дитини інтелект відіграє важливу роль, набуває яскраво вираженого пізнавального характеру, підпорядковується завданню навчатися, зберігати інформаційний матеріал, відбувається інтенсивне формування прийомів запам'ятовування. Швидко розвиваються вольові процеси.

Криза семи років є перехідним періодом, що відділяє дошкільне дитинство від молодшого шкільного віку. Це криза саморегуляції, яка нагадує кризу першого року. Ї̈і основні симптоми:

1. Втрата безпосередності поведінки. Між бажаннями та вчинками вклинюються внутрішні переживання щодо правомірності чи доцільності своїх дій.

2. Манірність поведінки. Намагаючись виправдати сподівання дорослих, дитина відверто демонструє навіть ті позитивні якості, які їй не властиві.

3. Симптом. «гіркої иукерки». Дитині погано, але вона намагається це приховати.

Семирічна дитина не може стримувати свої почуття, не вміє керувати ними. Втративши одні форми поведінки, вона ще не опанувала інші. Виникають труднощі у вихованні, дитина замикається в собі і часто стає не керованою. Як вважає Л.Божович, криза 7 року життя - це період зародження соціального «Я» дитини [5]. Криза потребує переходу до нової соціальної ситуації. Дитині потрібно вступити у стосунки з суспільством як із сукупністю людей, які здійснюють обов'язкову, суспільно необхідну та корисну діяльність. Усе, що стосується навчання, виходить на перший план, а те, що пов'язане з грою, стає менш важливим. Зазначені зовнішні особливості поведінки семирічної дитини так само, як і схильність до капризів, афектних реакцій, конфліктів, починають зникати, коли дитина виходить із кризи і вступає в новий вік - підлітковий. Протягом більш як півстоліття йде теоретична дискусія про роль біологічних і соціальних моментів у виникненні явища критичного розвитку в підлітковому віці. Істотні зміни в організмі підлітка слугують основою різних теорій про біологічну зумовленість кризи в підлітковому віці. При цьому слід, насамперед, згадати ідеї С. Холла (18441924 рр.) про те, що підлітковий вік у розвитку особистості відповідає епосі романтизму в історії людства. Він сформулював уявлення про перехідність підліткового віку - періоду «бурі і натиску», виділив змістово-негативні характеристики цього етапу - важковиховуваність, конфліктність, емоційну нестійкість; визначив позитивне надбання віку - «почуття індивідуальності» [7].

На думку психоаналітиків (3. Фрейд, А. Фрейд), підлітковий період співвідноситься 3 генітальною стадією, коли статеве дозрівання, зростання сексуальної енергії $\epsilon$ передумовою порушення рівноваги між структурами особистості Е. Шпрангер також розглядав цей період як кризовий. Зміст кризи полягає у звільненні від дитячої незалежності [7]. Таким чином, психологічні зміни, що відбуваються в розвитку особистості підлітка, представники біологізаторського напрямку пов'язували, 3 процесом статевого дозрівання. У другій половині XX ст. інтенсивно почали розвиватися уявлення про роль середовища в розвитку підлітка. Ці уявлення заперечують гіпотезу про біологічну зумовленість, генетичну запрограмованість кризи, а на перший план виходять соціальні чинники, які визначають тривалість підліткового періоду, наявність чи відсутність кризи, конфліктів, труднощів, характер самого переходу від дитинства до дорослості. Ці погляди можна знайти у працях Е. Еріксона, Ж. Піаже, а також культурантропологів (М. Мід, Р. Бенедикт) [7].

Л.С. Виготський виокремив основне новоутворення в свіомості і з'ясував соціальну ситуацію розвитку, при цьому зробивши висновок, що головний зміст кризи перехідного періоду складає перебудова системи відносин між дитиною і середовищем [4]. У вітчизняній психології вікова криза розглядається як цілісна зміна особистості дитини, яка регулярно виникає на межі стабільних періодів. Вона зумовлена виникненням основних психологічних новоутворень попереднього стабільного періоду, які приводять до руйнування однісї соціальної ситуації розвитку і виникнення іншої (Л.С. Виготський). Поведінкові критерії кризи - важковиховуваність, конфліктність, впертість, негативізм тощо - $\epsilon$ необхідними, в них виявляється єдність негативних і позитивних сторін вікової кризи.

Випуск 11, 2018. Збірник наукових праць РДГУ 
Підліткова криза - це різка зміна всієї системи переживань підлітка, іiї структури і змісту. Закономірним явищем є протиставлення підлітка дорослим i активне завоювання нової позиції. Підліток нібито провокує заборони, щоб перевірити власні сили в подоланні цих заборон, розширити межі, які визначають його самостійність. Саме це зіткнення дає підлітку інформацію про себе, свої можливості, задовольняє потребу в самоствердженні. Криза підліткового віку проходить три фази: негативну (передкритичну) - фазу руйнування старих звичок, стереотипів; кульмінаційну - фазу загострення протиріч; посткритичну - фазу формування нових структур, побудови нових стосунків. Отже, підлітковий вік - це період вікової кризи, зміст якої полягає в задоволенні підлітком потреби в самопізнанні і самоствердженні через боротьбу за незалежність у відносно безпечних умовах, яка не набуває крайніх форм, при цьому кризові симптоми - це епізодичні явища, інтенсивність і способи вираження яких різні. Особливості прояву і перебігу підліткової кризи визначаються конкретними соціальними умовами, положенням підлітка в світі дорослих.

Юність є початком дорослого життя. У цьому віці виникає відчуття того, що все життя попереду, а це дає можливість пробувати, помилятися і вести пошук. Дитинство залишається у минулому. Всі психічні функції в основному сформовані і почалася стабілізація особистості, рамки окремих вікових періодів носять все більш умовний характер. Криза 17 років - рубіж звичного шкільного і нового дорослого життя. У випадку, коли діти покидають стіни школи після 9-го класу, йдуть у коледжі або працювати, відбувається зсув кризи 17 років у бік кризи 15 років. Криза 15 років характерна переважно для тих, хто має сильну установку гедонізму. Під час кризи такі підлітки бувають цинічні і достатньо відверті, ясно формулюють своє життєве кредо. Період юності для них час спроб і помилок. У 17 років криза протікає не менш гостро, ніж у 15 років. Д.Б. Ельконін відзначав це як найважчий кризовий період разом 3 кризою 3-х років. Більшість 17-річних орієнтується на продовження освіти, небагато - на пошук роботи. Вища освіта їм необхідна, насамперед, для того щоб одержати професію, що дозволяє «жити гідно», «багато заробляти», «забезпечувати себе і сім'ю» [4]. Існують дві категорії випускників школи: перші сподіваються на допомогу батьків (платний ВЗО) і не втрачають душевної рівноваги; другі розраховують на свої сили - найбільш схильні до пов'язаних зі вступом до ВЗО стресів. Для тих, хто важко переживає кризу 17 років характерні різні страхи. Відповідальність за зроблений вибір, реальні досягнення в цей час вже великий вантаж. Сюди ще додаються страхи перед новим життям, перед можливістю помилки, перед невдачею під час вступу до ВЗО, у хлопців - перед армією. Висока тривожність і виражений страх можуть привести до виникнення невротичних реакцій (загостренню гастриту, нейродерміту, головних болів, тиску) й інших хронічних захворювані. Але якщо навіть випускник малотривожний, $\mathrm{i}$ все складається вдало, різка зміна способу життя, включення в нові види діяльності, спілкування 3 іншими людьми викликають значну напруженість. Нова життєва ситуація вимагає адаптації до неї. Допомагають в цьому впевненість в собі, відчуття компетентності, підтримка сім’ї і інше.

Криза юнацького віку нагадує кризи 1-го року (мовна регуляція поведінки) і 7-ми років (нормативна регуляція). У 17 років відбувається ціннісно-смислова саморегуляція поведінки. У молодої людини спостерігаться філософська інтоксикація свідомості, вона виявляється заглибленою в сумніви, роздуми, що заважають іiі активній дальній позиції. Іноді стан переходить в ціннісний релятивізм (відносність всіх цінностей). Криза юнацького віку з'являється зі вступом молодої людини до дорослого життя, коли загострюються внутрішні конфлікти, виникають питання, які здаються неможливими для розв'язання, життя стає складнішим. У загальнішому контексті юність забезпечує створення системи цінностей, які виступають показниками реалізованих потреб і конкретних дій, і які в подальшому життєствердженні особистості спрямовані на відпрацювання ефективних поведінкових стратегій. Загалом, в юності формується світоглядна установка людини на реалізацію та самореалізацю в соціальному оточенні. Саме 3 таких міркувань кожна людина має переходити в інший вимір власного життя - вимір дорослості. Від того, наскільки якісно відбулися зміни у структурі самосвідомості людини в підлітковому віці, а у світогляді - в юнацькому, буде залежати й ефективність у реалізації суб'єктивно значущих завдань наступних вікових етапів. Гейл Шихі визначає певну категорію людей, які протягом свого життя так і залишаються «безтурботними юнаками» [4]. Тобто криза юності, що може відбуватися непоміченою для самої людини, коригує та визначає iї подальшу життєву перспективу.

Щодо завдання юнацького періоду розвитку людини, то воно є досить специфічним, а саме створення репрезентативного плану на подальше життя (Ш. Бюллер). Не виникає сумнівів, що цей план $є$ певною альтернативою для молодої людини у співставленні реальних аспектів життя (в контексті теперішнього) та перспективних, інколи фантастичних планів його бачення у майбутньому. У більшості випадків визначення альтернативного плану на подальше життєствердження в період юності самою молодою людиною 3 позиції соціуму та значимих близьких сприймається як 
мрійливість та авантюрність і не завжди отримує схвалення. Саме тому завершення й отримання вищої освіти зорієнтовує молодь на обмежену найближчу перспективу, яка має підтверджувати професійну належність і не вимагає чіткого визначення реальних життєвих прагнень. Загалом, часова локалізація життєвих амбіцій має бути набагато ширшою, аніж констатація і знаходження, наприклад, роботи.

Висновки 3 даного дослідження і перспективи подальших розвідок. Таким чином, у статті проаналізована проблема вікових криз та їх значення у розвитку і зростанні дитини від народження до юнацького віку. Дана проблема $є$ однією 3 найважливіших для батьків, лікарів, учителів, вихователів. Тому необхідно знати вікові особливості розвитку дитини і створювати їй оптимальні умови. Організм дитини багато в чому відрізняється від організму дорослого. Процеси росту і розвитку дитини протікають нерівномірно, хвилеподібно, стрибками i підлягають певним закономірностям. Межами деяких періодів дитинства є вікові кризи. Знаючи про особливості їх перебігу, можна уникнути багатьох неприємних моментів і допомогти дитині перейти до нового періоду розвитку.

Звичайно, в цій сфері ще дуже багато напрямків для подальших досліджень. Проблема криз і виходів 3 них, на сьогоднішній день - одна 3 найбільш перспективних і актуальних проблем психології.

\section{Список використаних джерел}

1. Забродський М. М. Основи вікової психології : навч. посіб. / М. М. Забродський. Тернопіль : Богдан, 2003. - 112 с.

2. Генцл 3. Криза як ритуал переходу. Ідеї до конструктивістсько-системної концептуалізації кризи та кризової інтервенції / 3. Генцл ; [пер. з нім.]. - Львів, 1998. - 22 с.

3. Кононко О. Л. Соціально-емоційний розвиток особистості (в дошкільному дитинстві) : навч. посіб. для вищ. навч. закл. / О. Л. Кононко. - Київ : Освіта, 1998. -255 с.

4. Кузьменко В. У. Відверті розмови дитячого психолога з батьками / В. У. Кузьменко, О. Г. Кобернік. - Київ : Пора-прінт, 2002. - 83 с.

5. Основи практичної психології : підручник / В. Панок, Т. Титаренко, Н. Чепелєва та ін. Київ : Либідь, 1999. - 536 с.

6. Павелків Р. В. Вікова психологія : підручник / Р. В. Павелків. - Київ : Кондор, 2011. - 469

c.

7. Павелків Р. В. Дитяча психологія : навч. посіб. / Р. В. Павелків, О. П. Цигипало. - Київ : Академвидав, 2008. - 432 с. - (Альма-матер).

\section{References}

1. Zabrodsky M. M. The Basis of Age Psychology : a manual / M. M. Zabrodsky. - Ternopil : Bogdan, 2003. - $112 \mathrm{p}$.

2. Gentsl Z. Crisis as a ritual of transition. The Ideas for Constructivist-Systemic Crises Conceptualization and Crisis Intervention / Z. Gentsl ; [translated from German]. - Lviv, 1998. - 22 p.

3. Kononko O. L. Socio-emotional development of personality (in pre-school childhood) : reaching manual for higher educational establishments / O. L. Kononko. - Kyiv : Education, 1998. - 255 p.

4. Kuzmenko V. U. Sincere conversations of children's psychologist with parents / V. U. Kuzmenko, O. G. Kobernik. - Kyiv : Pora-Print, 2002. -83 p.

5. The Basis of Practical Psychology : Textbook / V. Panok, T. Tytarenko, N. Chepelieva and others. - Kyiv : Lybid, 1999. - 536 p.

6. Pavelkiv R. V. Age Psychology : pidruchnyk / R. V. Pavelkiv. - Kyiv : Condor, 2011. - 469 p.

7. Pavelkiv R. V. Children's Psychology : teaching manual / R. V. Pavelkiv, O. P. Tsyhypalo. - Kyiv : Akademvidav, 2008. - 432 p. - (Al'ma-mater).

\section{O. D. Biletska THE PSYCHOLOGICAL ASPECTS OF AGE CRISES OF PERSONALITY FROM BIRTH TO ADOLESCENCE}

The article is devoted to the dynamics of changes in age stages of development. The beginning and end of each age stage is the experience of crises which lead to new qualitative changes in the psychological and social personality context. The matter of the theoretical analysis of age crises from birth to adolescence is extremely relevant, as rapid changes in society stimulate the child to continuous development and the lability of social norms erodes the guidelines for the development of personal identity. Among the various forms of identity the most common and distinguished are the age-old benchmarks as the basis for selfidentification of the child's personality. 
The article deals with the theoretical analysis of age crises from birth to adolescence as regular stages of mental development of the child's personality. The chronological limits of age crises are determined. The classification of signs, symptoms and typology of age crises is carried out. It is noted that age crises make constructive neoplasms in the structure of the individual with a help of which a personality receives a new experience, which is divided into internal or subjective and social (external) or objective. The study of the psychological patterns of personality's age crises (symptoms, features of development, major neoplasms) will allow to develop general principles and individual strategies for psychological support of the child's personality during the periods of crises. It is one of the essential reasons that causes the need to develop a general psychological concept of age crises of personality development.

Key words: critical periods, stable periods, an age crisis, a newborn crisis, a recovery complex, 3 years old crisis, 6-7 years old crisis, a teenage crisis, an adolescence crisis. 